\title{
Post-Surgical Effects of Roux- En-Y Gastric Bypass on Glucose Homeostasis, Intestinal Morphology and L-Cells in Obese Göttingen Minipigs
}

\begin{abstract}
Keywords: Bariatric surgery; Gastric bypass; RYGB; Intestinal morphology; L-cells; Minipig; Obesity

Abstract

Background: Roux-en-Y gastric bypass (RYG B) is currently the most effec tive treatment of morbid obesity in man. In rodents, RYG B leads to a number of morphological changes in the intestine. However, little is known about the effect of RYG B surgery on intestinal morphology and enteroendocrine L-cells in largeranimalsand man. Here we performed RYGB surgery in obese Göttingen minipigs, to assess whether the intervention is associated with changes in intestinal volume, L-cell number and plasma levels of gluc ose, insulin, glucagon-like peptide-1 (GLP-1) and leptin.
\end{abstract}

Methods: The study included five RYGB operated and three nonoperated obese Göttingen minipigs (body weight $99 \pm 7.7 \mathrm{~kg}$ ). Pla sma samples were obtained for assessment of glucose, insulin, GLP-1 and leptin pre- and post- RYGB surgery. The pigs were euthanized eight to nine months post-surgery and the gut processed for stereologica assessments of intestinal volume and L-cell number.

Results: RYGB led to a sustained reduction of body weight of $\sim 14 \%$ in two animals (responders), whereas three a nimals regained body weight to pre-surgical levels (non-responders). Postprandial plasma levels of glucose and insulin were unchanged in all animals post-surgery, whereas postprandial GLP-1 levels increased in both responders and non-responders and leptin levels decreased with the most pronounced improvement in responders. Variations in body weight loss were reflected in changes in length of alimentary limb, intestinal volume and total L-cell number of the a limentary limb.

Conclusion: Body weight loss following RYGB surgery in obese Göttingen minipigs is associated with an increase in intestinal volume, total L-cell number, and postprandial plasma GLP-1 levels. These changes are most pronounced in the alimentary limb suggesting that the changes here may be a key determinant to the success of RYGB surgery.

\section{Abbreviations}

RYGB: Roux-en-Y Gastric Bypass; GLP-1: Glucagon-Like Peptide-1; GLP-2: Glucagon-Like Peptide-2; IVGTT: Intra Venous Glucose Tolerance Test; MMT: Mixed Meal Test; PYY: Peptide YY

\section{Introduction}

Obesity is considered one of the most serious threats to public health with over 2.8 million people dying each year due to obesity related pathology [1]. Currently, only a few pharmacological treatments are available, which all show poor efficacy and/or many adverse effects. In contrast, bariatric surgery including Roux-en-Y gastric bypass (RYGB) leads to sustained weight loss, but also

\section{Journal of \\ Obesity and Bariatrics}

Pernille Barkholt ${ }^{1 *}$, Andreas Vegge ${ }^{2,3}$, Trine Ryberg Clausen ${ }^{3}$, Malene Muusfeldt Birck ${ }^{4}$, Johannes Josef Fels ${ }^{3}$, Mikael Støckel ${ }^{5}$, Ismail Gögenur ${ }^{5}$, Thomas Eriksen ${ }^{6}$, Jens Juul Holst ${ }^{7}$, Axel Kornerup Hansen ${ }^{4}$, Thomas Thymann ${ }^{2}$, Jacob Jelsing ${ }^{1}$, Per Torp Sangild ${ }^{2}$ and Kirsten Raun ${ }^{3}$

${ }^{1}$ Department of Histology, Gubra, Hørsholm, Denmark

${ }^{2}$ Department of Nutrition, Exercise and Sports, Faculty of Science, University of Copenhagen, Denmark

${ }^{3}$ Diabetes research unit, Novo Nordisk A/S, Måløv, Denmark

${ }^{4}$ Department of Veterinary Disease Biology, Faculty of Health and Medical Sciences, University of Copenhagen, Denmark

${ }^{5}$ Department of Surgery, Copenhagen University Hospital, Herlev, Denmark

${ }^{6}$ Department of Veterinary Clinical and Animal Science, Faculty of Health and Medical Sciences, University of Copenhagen, Denmark ${ }^{7}$ Novo Nordisk Foundation, Centre of Basic metabolic Research, Department of Biomedical Sciences, Panum Institute, Copenhagen, Denmark

\section{*Address for Correspondence}

Pernille Barkholt, Department of Histology, Gubra, Agern Allé 1, 2970 Hørsholm, Denmark, Tel: +45 31522650; E-mail: pb@gubra.dk

Copyright: (c) 2015 Barkholt $\mathrm{P}$, et al. This is an open access article distributed under the Creative Commons Attribution License, which distributed under the Creative Commons Attribution License, which
permits unrestricted use, distribution, and reproduction in any medium, permits unrestricted use, distribution, and
provided the original work is properly cited.

Submission: 03 January 2015

Accepted: 19 January 2015

Published: 24 January 2015

Reviewed \& Approved by: Dr. Francesco Saverio Papadia,

Assistant Professor of Surgery, University of Genoa School of Medicine, Italy

resolution of type 2 diabetes mellitus and improvement in other comorbidities like arterial hypertension and atherosclerosis $[2,3]$.

Not all individuals respond equally well to RYGB surgery and the exact mechanisms underlying the weight loss and anti-diabetic effects are not fully understood. It is generally accepted that release of gut hormones such as glucagon-like-peptide 1 (GLP-1) and peptide YY (PYY) as well as intestinal growth factors play important roles $[4,5]$. Previous studies have consistently shown increased plasma levels of GLP-1 and PYY following RYGB [6-8]. Moreover, a number of studies in rodent models have demonstrated marked changes in intestinal volume and number of GLP-1 positive enteroendocrine cells following RYGB surgery, as well as altered GLP-1 and PYY mRNA gene expression in the gut $[9,10]$. Collectively, these data suggest that the post-surgical effect of gastric bypass on intestinal morphology and endocrine cell numbers play an important role for the weight loss and other beneficial effects seen after RYGB surgery.

The minipig has been proven to be a valuable animal model for human nutrition and obesity studies due to similarities in gastrointestinal tract anatomy, nutrition requirements, body size and metabolic characteristics [11,12]. Anatomical similarities include the epithelial cell types and structure of the intestinal villi [13]. Furthermore, pigs are omnivores and their diet composition, gastric $\mathrm{pH}$ and digestive effectiveness resemble that of humans [12]. In response to both feeding and fasting the release of gut hormones such as ghrelin, leptin and PYY has been shown to mirror that of humans 
Citation: Barkholt P, Vegge A, Clausen TR, Birck MM, Fels JJ, et al. Post-Surgical Effects of Roux-En-Y Gastric Bypass on Glucose Homeostasis, Intestinal Morphology and L-Cells in Obese Göttingen Minipigs. J Obes Bariatrics. 2015;1(1): 8.

$[14,15]$ collectively making the pig a useful model for studying aspects of human nutrition [16] and gastrointestinal disorders [17,18].

The Göttingen minipig has the same anatomical and physiological features as the domestic pig but their smaller size and a growth phase that is more comparable with that of humans, give them an advantage as experimental models $[19,20]$. On a restricted diet, the adult Göttingen minipig weighs 35-40 kg. However, when given ad libitum access to food especially the females will overeat and reach a body weight of more than $100 \mathrm{~kg}$ by 18 months of age [21,22]. This leads to a model of obesity that is more similar to human obesity than rodent models with respect to body composition [22-24]. In addition, obese minipigs have been reported to develop mild insulin resistance while maintaining normal glucose tolerance which is similar to observations in some obese humans $[20,25]$. Previous studies have shown that RYGB in minipigs induces an increase in both fasted and postprandial ghrelin levels whereas plasma levels of PYY remain unchanged [26]. Furthermore, two recent studies have examined physiological effects of RYGB in lean pigs. One study shows that RYGB in young castrated male lean pigs leads to increased $\beta$-cell mass, improved glycemic control and increased number of pancreatic GLP1 receptor positive cells [27]. Whereas the other paper demonstrates elevated postprandial insulin and GLP-1 levels following RYGB in lean Göttingen minipigs [28]. However, until now the majority of RYGB studies in pigs have focused on method development or short-term survival, and all studies have been performed in lean pigs $[26,29]$. So far no studies have investigated the postsurgical effects of RYGB on the small intestine and glucose metabolism in obese Göttingen minipigs.

The aim of the current study is to characterize post-surgical changes in intestinal morphology and number of L-cells in obese RYGB Göttingen minipigs, and to correlate these changes to weight loss and plasma hormone levels, such as GLP-1.

\section{Methods}

\section{Animals}

Eleven female ovariectomized obese Göttingen minipigs (Ellegaard Göttingen minipig A/S, Denmark) aged 4-6 years underwent laparoscopic RYGB surgery. At the time of surgery, body weight ranged from $88-122 \mathrm{~kg}$. This is more than double of what is considered normal body weight for Göttingen minipigs, and resembling morbid obesity in humans [11]. Diet-induced obesity was initiated by giving ad libitum access to standard minipig chow (Altromin 9023, Brogaarden, Denmark). Animals were single housed in pens with straw bedding and free access to water. Two days prior to surgery, the pigs had access to limited liquid diet only (Nutridrink Cocoa, Nutricia, Denmark) and three to four weeks after surgery animals were gradually returned to ad libitum chow. Three ovariectomized obese minipigs with a body weight of 91-111 $\mathrm{kg}$ were included as non-operated controls. Animals were treated in accordance with the Animal Experimentation Act of Denmark, which is in accordance with the Council of Europe Convention ETS 123. All animal experiments were approved by the Danish Committee for Animal Research (permit number 2012-15-2934-00058).

\section{Surgery}

Approximately one month before RYGB surgery, two central venous catheters were surgically implanted in the external jugular vein during anesthesia [30].
A detailed description of the anesthesia, the RYGB surgical procedure and the pre- and post-surgical management of the minipigs has been described elsewhere [30]. Briefly, a gastric pouch of estimated 20-30 mL was created along the lesser curvature of the stomach with the remaining part of the stomach being bypassed. A gastro-jejunostomy was created between the jejunum $120 \mathrm{~cm}$ aborally from the duodenum and the gastric pouch. Following, another 240 $\mathrm{cm}$ of the intestine a jejuno-jejunostomy was created, right next to the initial gastro-jejunostomy. By dividing the intestine between the two anastomoses a biliopancreatic limb of $120 \mathrm{~cm}$, an alimentary limb of $240 \mathrm{~cm}$ and a common limb of 500-600 cm were created.

\section{Mixed meal test (MMT)}

An MMT was performed before surgery as well as one month and three months after surgery in the five RYGB animals. Animals were fasted overnight with free access to water. $200 \mathrm{~mL}$ of Nutridrink Cocoa (per $100 \mathrm{~mL}: 1260 \mathrm{~kJ}, 6.0 \mathrm{~g}$ protein, $5.8 \mathrm{~g}$ fat, $18.4 \mathrm{~g}$ carbohydrate) was administered intraorally at $\mathrm{t}=0$. Blood samples for plasma leptin and GLP-1 analyses were collected at $\mathrm{t}=-10,-5,0,15,30,45$, $60,90,120,180$ and 240 minutes through one of the central venous catheters. Blood was collected in tubes containing EDTA $(8 \mathrm{mM}$, Sigma \#E0270), DPPIV inhibitor $(1 \mu \mathrm{g} / \mathrm{ml}$ blood, Linco DPP4-010), protease inhibitor cocktail ( $10 \mu \mathrm{l} / \mathrm{ml}$ blood, Sigma \#P8340), Pefabloc SC (AEBSF) $(10 \mu \mathrm{l} / \mathrm{ml}$ blood, Roche\#11 429868 001), and aprotinin (500 KIE/ml blood, Trasylol, Bayer). Plasma was separated and stored at $-80^{\circ} \mathrm{C}$ until further analysis.

\section{Intravenous glucose tolerance test (IVGTT)}

Prior to surgery and one month post-operatively an IVGTT was performed in the five RYGB animals. Animals were fasted overnight with free access to water. At $\mathrm{t}=0$ a bolus $0.3 \mathrm{~g} / \mathrm{kg}$ of a $50 \%$ sterile glucose solution was administered intravenously through one of the central venous catheters. Blood samples for glucose, insulin and C-peptide were taken through the second catheter at $\mathrm{t}=-10,-5,1,3$, $5,7,10,15,20,25,30,40$ and 55 minutes. Plasma was separated and stored at $-80^{\circ} \mathrm{C}$ until further analysis. Plasma glucose was measured immediately after centrifugation by transferring $10 \mu \mathrm{L}$ of plasma into $500 \mu \mathrm{L}$ EBIO solution and measured on a Biosen auto analyzer (BIOSEN S Line, EKF Diagnostics, Cardiff, UK) according to the manufacturer's instructions.

\section{Assays}

GLP-1 and leptin levels were measured in plasma from MMT and plasma insulin and C-peptide were measured from IVGTT. Intact GLP-1, insulin and c-peptide were measured using Luminescence Oxygen Channeling Immunoassays (LOCI) as described previously [31]. Two monoclonal antibodies against GLP-1 (mAbF5 [32] and mAb26.1 [33] recognizing different epitopes were used in the GLP1 assay. For insulin and C-peptide in-house monoclonal antibodies recognizing different epitopes of porcine insulin and porcine C-peptide respectively were used. All samples were measured in duplicate and results reported as the mean of duplicates.

Leptin was measured in EDTA-stabilized plasma using a multispecies Leptin RIA kit (Millipore, Cat \# XL-85K) according to the manufacturer's protocol. Results are reported as the mean of duplicates.

\section{Tissue sampling}

Eight to nine months after surgery the pigs were euthanized with 
Citation: Barkholt P, Vegge A, Clausen TR, Birck MM, Fels JJ, et al. Post-Surgical Effects of Roux-En-Y Gastric Bypass on Glucose Homeostasis, Intestinal Morphology and L-Cells in Obese Göttingen Minipigs. J Obes Bariatrics. 2015;1(1): 8.

an overdose of pentobarbital. The entire small bowel was sampled immediately after termination and the lengths of alimentary, biliopancreatic and common limbs were recorded. Tissue samples were obtained from each of the three limbs using systematic uniform random sampling (SURS) principles ensuring an unbiased representation of the entire region [34]. Using this principle, eight transverse biopsies were obtained from each limb. The biopsies were immersion fixed in $4 \%$ formaldehyde and stored at $4^{\circ} \mathrm{C}$ until further processing. In the control animals, the three limbs of the small intestine were delineated based on the averaged limb length in the operated animals (16\% alimentary, $18 \%$ biliopancratic and $66 \%$ common limb). The corresponding intestinal segments of these animals were then sampled in the same way as the RYGB operated animals using SURS.

\section{Embedding and sectioning}

The eight biopsies from each limb were paraffin infiltrated overnight and then embedded in paraffin blocks, one biopsy in each block. The blocks were subsequently cut in $5 \mu \mathrm{m}$ thick sections using a Microm HM340E (Thermo Scientific, Walldorf, Germany) and collected on glass object slides (Thermo Scientific, Walldorf, Germany). One series consisting of one section from each biopsy was collected for histochemical staining and subsequent analysis of mucosal surface and volume. Another series consisting of two consecutive sections arranged on one object slide was collected for immunohistochemical staining and L-cell quantification.

\section{Histochemical and immunohistochemical staining}

Quantitative evaluation of intestinal volume and mucosal surface was conducted on haematoxylin-eosin (HE) using Mayer's Haematoxylin solution (MHS32-1L, Sigma Aldrich) and Eosin B solution (HT110280, Sigma-Aldrich). GLP-1 immunohistochemistry was performed according to standard staining protocols $[10,35]$ using a primary mouse anti-GLP-1 antibody (GLPa-1F5 0P009, 1:1000) in combination with EnVision ${ }^{+}$HRP labelled polymer antimouse (K4007, DAKO, Denmark) using a diaminobenzidine (DAB) as chromogen (K3468, DAKO, Denmark). All slides were scanned and digitized using an Aperio ScanScope AT slide scanner (Aperio, California, USA) with a $20 x$ objective.

\section{Stereological quantification of regional volumes and mucosa surface}

All stereological parameters were estimated using the new CAST software (Visiopharm, Hørsholm, Denmark) on digital slides. Volumes of the intestinal wall were estimated in each of the different intestinal limbs using point counting, and converted into volume using the principle of Cavalieri:

$$
\mathrm{V}_{\text {ref }}=\sum \mathrm{P} \times \mathrm{A}_{\text {point }} \times \mathrm{t}
$$

Where $\Sigma \mathrm{p}$ is the total number of points hitting the structure of interest, $A_{\text {point }}$ is the area associated with each grid point and $t$ is the distance between sections [36].

Estimation of the inner mucosal surface area was performed by counting intersections between linear probes and the luminal side of the intestine [34,35]. The absolute surface area was estimated by the relationship between intersection and point counts multiplied with the reference volume:

$$
\mathrm{S}=\frac{2 \times \sum \mathrm{I}}{\mathrm{l}_{\text {probe }} \times \sum \mathrm{P}} \times \mathrm{V}_{\text {ref }}
$$

Where $\sum \mathrm{I}$ is the number of intersections of the test lines with the epithelium of the tunica mucosa, $1_{\text {probe }}$ is the length of the test line and $\Sigma \mathrm{P}$ is the number of test points hitting the reference volume.

\section{Stereological quantificationtion of $\mathrm{L}$-cell number}

The total number of GLP-1 immunoreactive L-cells was estimated using the principle of the physical dissector [34] at an on-screen magnification of $640 \mathrm{x}$. The numerical density $\left(\mathrm{N}_{\mathrm{v}}\right)$ of L-cells was estimated by counting cells within a reference volume [36]:

$$
\mathrm{N}_{\mathrm{V}}=\frac{\sum \mathrm{Q}^{-}}{\sum \mathrm{P} \times \mathrm{a}_{\text {frame }} \times \mathrm{t}}
$$

Subsequently, the total number of L-cells was obtained by multiplying the numerical density with the total mucosa volume.

\section{Statistical evaluation}

Graphical presentations, calculations and statistical analyses were carried out using GraphPad software (GraphPad Prism version 5.04, California USA). Graphical presentations illustrate individual data as well as linear correlations (evaluated by Pearson correlation test). Tables present data of control $(n=3)$, non-responders $(n=3)$ and responders $(n=2)$. Due to the low numbers of animals, no statistical analyses were performed between groups. Data are presented as mean \pm standard error of the mean (SEM).

\section{Results}

\section{Survival and body weight}

Five successfully RYGB operated animals were included in this study and compared with three non-operated obese controls. The six remaining animals that underwent RYGB surgery were euthanized pre-maturely due to surgical or central venous catheter related complications and therefore excluded from further analyses (see [30]). Initially, all five RYGB animals lost weight with an average weight loss of $9.1 \pm 0.9 \%$ eight weeks post-surgery. One animal continuously lost weight throughout the study (RYGB 1) whereas one animal started to slowly regain weight from 10 weeks after surgery (RYGB 2). RYGB 1 and RYGB 2 are referred to as responders and maintained a reduced body weight throughout the experimental period ( $86 \pm 12 \%$ compared to their pre-surgical weight) (Figure 1). In contrast, three animals started to regain weight approximately two months post-surgery, eventually leading to a body weight exceeding the body weight at time of surgery $(108 \pm 1.3 \%$ compared to their pre-surgical weight) (Figure 1). These animals are referred to as nonresponders (RYGB 3, 4 and 5).

\section{Plasma hormones}

Area under curve analysis of plasma glucose, insulin and c-peptide in response to intravenous glucose administration, showed similar levels of these hormones between responders and non-responders compared with pre-surgery levels (Table 1).

Fasting leptin levels were decreased for both responders and 
Citation: Barkholt P, Vegge A, Clausen TR, Birck MM, Fels JJ, et al. Post-Surgical Effects of Roux-En-Y Gastric Bypass on Glucose Homeostasis, Intestinal Morphology and L-Cells in Obese Göttingen Minipigs. J Obes Bariatrics. 2015;1(1): 8.

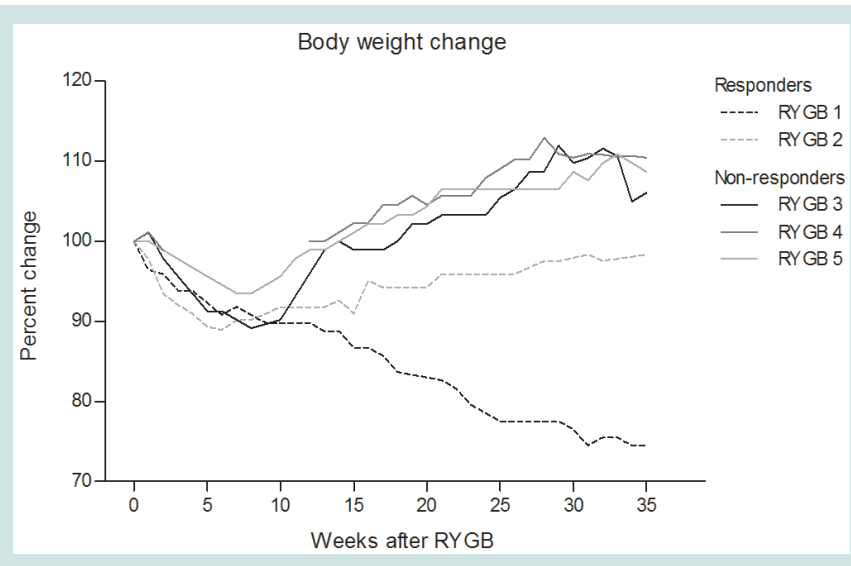

Figure 1: Body weight change. Body weight change in individual animals relative to body weight one week before surgery.

non-responders one month post-surgery compared with pre-surgical levels and the decrease remained at three months post-surgery (Table 2). The improvement in leptin levels was most pronounced in the responder animals. The leptin levels did not change in response to the mixed meal (data not shown). Fasting plasma levels of GLP-1 were unchanged after surgery, however, increased in response to the MMT at one and three months post-surgery in both responder and nonresponder animals compared with pre-surgical levels (Table 2).

\section{Gut morphology}

Representative images of gut morphology for the alimentary limb of control animals, responders and non-responders are shown in Figure 2 .

The length of the alimentary limb was identical between control and non-responder animals. Whereas, in responder animals this limb was 1.4 times longer than in both controls and non-responders (Table 3 and Figure 3A). A significant linear correlation between length of alimentary limb and body weight change was observed (Figure 3B).

The volume of the entire small intestinal was increased in all RYGB animals compared with the control animals (Figure 3C). Responder animals had a slightly larger volume than the non-responders (Table 4), however, no significant correlation between volume of the small intestine and body weight change was detected (Figure 3D). The hypertrophy was most pronounced in the alimentary limb and assessment of individual animals showed that the two responder animals had the highest degree of gut hypertrophy in alimentary limb volume (Figure 3E). As shown in Table 4 responders had a 2.7 fold larger alimentary limb volume than controls and a 1.8 fold increase compared with non-responders. Correlation analyses of individual body weight changes and individual alimentary limb volumes for the five RYGB animals demonstrated a significant linear relationship between weight loss and intestinal volume (Figure 3F).

\section{Number of L-cells and GLP-1 levels}

L-cells were identified by GLP-1 immunohistochemistry and representative images of control and RYGB animals are shown in Figure 4. The assessment of individual animals showed that the two responders had the highest total number of L-cells in the small intestine though no significant linear correlation was observed between total number of L-cells and weight change (Figures 5A and
5B). The hyperplasia was most pronounced in the alimentary limb, in fact in the alimentary limb the responder animals had a 3.0 fold increase in L-cell numbers compared with control animals and a 2.5 fold increase compared with non-responders (Table 5). Correlation analysis demonstrated a significant linear relationship between increased weight loss and number of L-cells in the alimentary limb of the five RYGB animals (Figure 5D). The increase in L-cell numbers in RYGB animals corresponded well with the increase in postprandial GLP-1 levels three months post-surgery, relative to their pre-surgery levels (Figures 5E and 5F).

\section{Discussion}

The present study aimed to investigate the effect of RYGB surgery on weight loss, hormone secretion, intestinal morphology and L-cell numbers in obese Göttingen minipigs. Using mathematically unbiased stereological methods, we report that RYGB surgery leads to a marked hypertrophy of the small intestine, in particular in the alimentary limb, an increased total number of L-cells, increased postprandial GLP-1 levels and decreased leptin levels. These findings are in line with previous reports from preclinical studies in rats $[9,10,37]$ and clinical observations from humans [7,8,37-39]. Furthermore, we report for the first time, data resulting from RYGB surgery in the obese Göttingen minipig, demonstrating a linear relationship between body weight loss, gut hypertrophy and L-cell numbers in responder versus non-responder animals. Collectively, the data suggest that the changes in the alimentary limb may be the key determinant to the success of RYGB surgery.

Table 1: Levels of plasma hormones in response to intravenous glucose bolus.

\begin{tabular}{|c|c|c|c|}
\hline & $\begin{array}{c}\text { Baseline } \\
\text { (pre-surgery) }\end{array}$ & $\begin{array}{c}\text { Non-responder } \\
\text { (RYGB 3,4 and 5) }\end{array}$ & $\begin{array}{c}\text { Responder } \\
\text { (RYGB 1 and 2) }\end{array}$ \\
\hline $\begin{array}{c}\text { C-peptide } \\
\text { AUC }\end{array}$ & $\begin{array}{c}31.5 \pm 3.1 \mathrm{pg} / \mathrm{mL} \\
\times \mathrm{min}\end{array}$ & $\begin{array}{c}37.3 \pm 2.4 \mathrm{pg} / \mathrm{mL} \\
\times \mathrm{min}\end{array}$ & $\begin{array}{c}39.9 \pm 1.1 \mathrm{pg} / \mathrm{mL} \\
\times \mathrm{min}\end{array}$ \\
\hline $\begin{array}{c}\text { Plasma } \\
\text { glucose } \\
\text { AUC }\end{array}$ & $622 \pm 41 \mathrm{mM} \times \mathrm{min}$ & $605 \pm 111 \mathrm{mM} \times \mathrm{min}$ & $661 \pm 86 \mathrm{mM} \times \mathrm{min}$ \\
\hline $\begin{array}{c}\text { Insulin } \\
\text { AUC }\end{array}$ & $\begin{array}{c}3635 \pm 4487 \mathrm{pM} \\
\times \min \end{array}$ & $\begin{array}{c}34585 \pm 5960 \mathrm{pM} \\
\times \min \end{array}$ & $\begin{array}{c}40514 \pm 10002 \mathrm{pM} \\
\times \min \end{array}$ \\
\hline
\end{tabular}

C-peptide, glucose and insulin plasma levels pre-surgery $(n=5)$ and one month post-surgery in non-responder $(n=3)$ and responder $(n=2)$ animals. All values are presented as mean \pm SEM

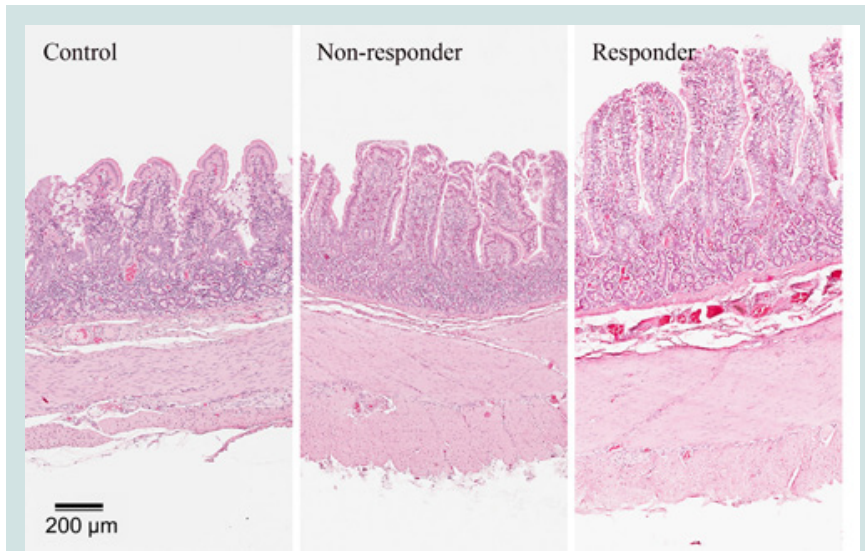

Figure 2: Gut morphology. Representative micrographs of gut morphology in the alimentary limb of control non-operated minipigs, non-responder and responder RYGB operated minipigs. Sections were stained with haematoxylin and eosin. 
Citation: Barkholt P, Vegge A, Clausen TR, Birck MM, Fels JJ, et al. Post-Surgical Effects of Roux-En-Y Gastric Bypass on Glucose Homeostasis, Intestinal Morphology and L-Cells in Obese Göttingen Minipigs. J Obes Bariatrics. 2015;1(1): 8.

Table 2: Levels of plasma hormones in response to oral mixed meal.

\begin{tabular}{|c|c|c|c|c|c|}
\hline & \multirow[b]{2}{*}{$\begin{array}{c}\text { Baseline } \\
\text { (pre-surgery) }\end{array}$} & \multicolumn{2}{|c|}{1 month post-surgery } & \multicolumn{2}{|c|}{3 months post-surgery } \\
\hline & & $\begin{array}{l}\text { Non-responder } \\
\text { (RYGB 3, } 4 \text { and 5) }\end{array}$ & $\begin{array}{c}\text { Responder } \\
\text { (RYGB } 1 \text { and 2) }\end{array}$ & $\begin{array}{l}\text { Non-responder } \\
\text { (RYGB 3, } 4 \text { and 5) }\end{array}$ & $\begin{array}{c}\text { Responder } \\
\text { (RYGB } 1 \text { and 2) }\end{array}$ \\
\hline $\begin{array}{l}\text { Leptin } \\
\text { Fasting }\end{array}$ & $15.95 \pm 1.52 \mathrm{mM}$ & $9.53 \pm 1.42 \mathrm{mM}$ & $8.12 \pm 1.37 \mathrm{mM}$ & $10.19 \pm 0.67 \mathrm{mM}$ & $7.74 \pm 0.58 \mathrm{mM}$ \\
\hline $\begin{array}{l}\text { GLP-1 } \\
\text { Fasting }\end{array}$ & $3.11 \pm 0.19 \mathrm{pM}$ & $2.99 \pm 0.94 \mathrm{pM}$ & $3.08 \pm 0.36 \mathrm{pM}$ & $3.01 \pm 0.86 \mathrm{pM}$ & $2.78 \pm 0.36 \mathrm{pM}$ \\
\hline $\begin{array}{l}\text { GLP-1 } \\
\text { AUC }\end{array}$ & $315 \pm 37 \mathrm{pM}^{\times} \min$ & $1491 \pm 718 \mathrm{pM}^{\times} \min$ & $1071 \pm 116 \mathrm{pM} \times \min$ & $2350 \pm 1220 \mathrm{pM} \times \min$ & $2412 \pm 845 \mathrm{pM} \times \min$ \\
\hline
\end{tabular}

Leptin and GLP-1 hormone levels pre-surgery $(n=5)$ as well as one and three months post-surgery in non-responder $(n=3)$ and responder $(n=2)$ animals. All values are presented as mean \pm SEM.

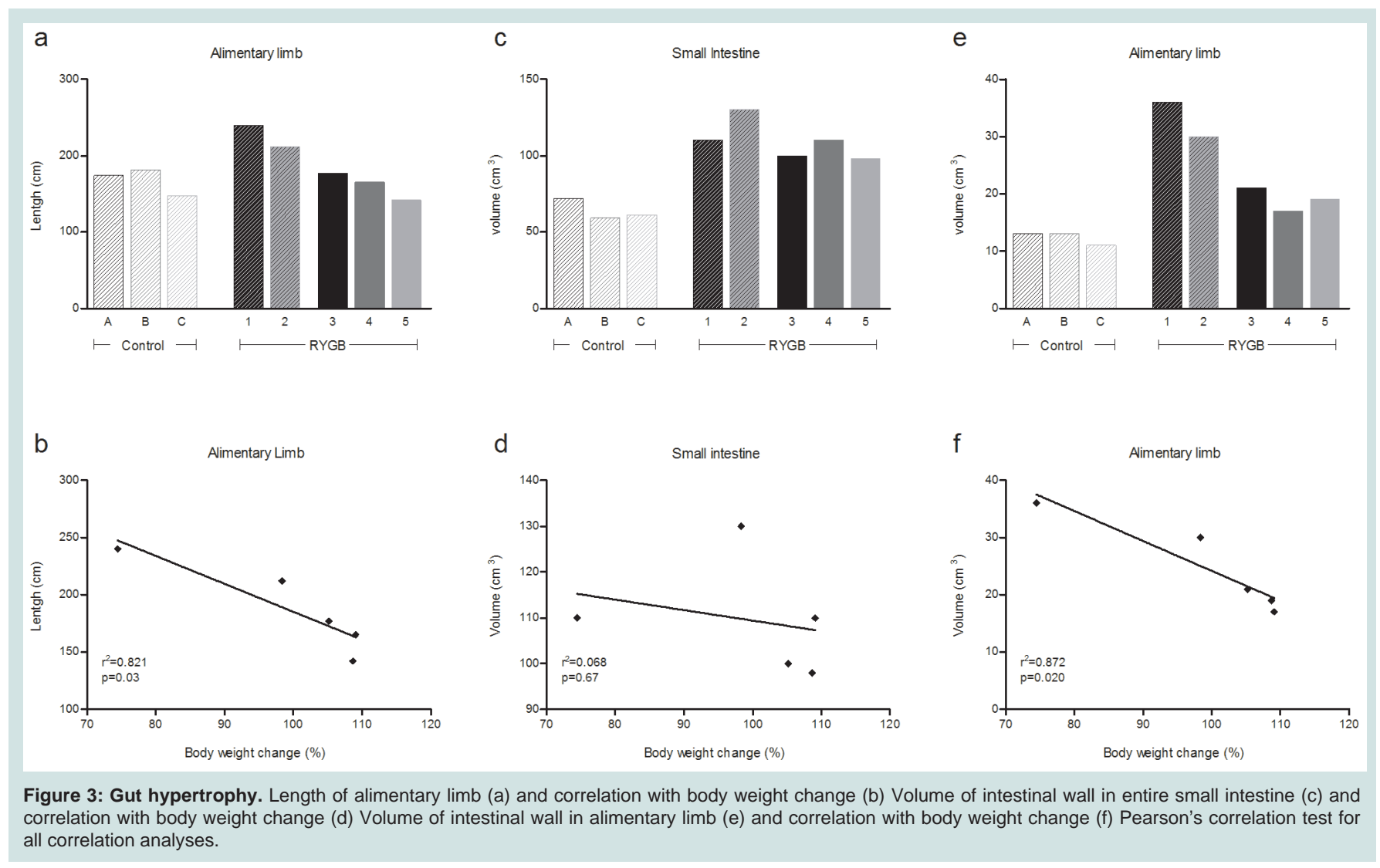

Table 3: Length of limbs in the small intestine.

\begin{tabular}{|c|c|c|c|}
\hline & $\begin{array}{c}\text { Control } \\
\text { (control A, B and } \\
\text { C) }\end{array}$ & $\begin{array}{c}\text { Non-responder } \\
\text { (RYGB 3, 4 and 5) }\end{array}$ & $\begin{array}{c}\text { Responder } \\
\text { (RYGB 1 and 2) }\end{array}$ \\
\hline Small intestine & $921 \pm 56 \mathrm{~cm}$ & $1049 \pm 74 \mathrm{~cm}$ & $1001 \pm 151 \mathrm{~cm}$ \\
\hline $\begin{array}{c}\text { Biliopancreatic } \\
\text { limb }\end{array}$ & $149 \pm 9 \mathrm{~cm}$ & $152 \pm 30 \mathrm{~cm}$ & $178 \pm 13 \mathrm{~cm}$ \\
\hline Alimentary limb & $167 \pm 10 \mathrm{~cm}$ & $161 \pm 10 \mathrm{~cm}$ & $226 \pm 14 \mathrm{~cm}$ \\
\hline Common limb & $605 \pm 37 \mathrm{~cm}$ & $736 \pm 42 \mathrm{~cm}$ & $598 \pm 153 \mathrm{~cm}$ \\
\hline
\end{tabular}

Length of intestinal limbs and the complete small intestine in control $(n=3)$, nonresponder $(n=3)$ and responder $(n=2)$ animals at termination. All values are presented as mean \pm SEM.

In this study we observed an alimentary limb that was 1.4 times longer in responder animals than in both control and non-responder animals, indicating that the length of this limb may be important for the success of RYGB surgery. Previous reports from clinical studies suggest that a longer alimentary limb is associated with an improved success of surgery (sustained weight loss) in super obese patients (BMI>50) [40-42] thereby supporting our findings. The difference in limb length in our study may of course be related to surgical variation, as it is very difficult to measure the lengths of the individual intestinal segments during the laparoscopic procedure. However, with a 3.0 fold increase in volume and a 2.7 fold increase in number of L-cells in the alimentary limb of responders compared with controls it is evident that these increases exceed the difference in length and demonstrates that post-surgical intestinotrophic effects are definitely taking place. Resting energy expenditure has been shown to be enhanced in animal models of gastric bypass and intestinal hypertrophy is expected to be a significant component of this $[37,43]$. The increased hypertrophy associated with a longer alimentary limb may therefore at least partially explain why these animals have an improved weight loss in our study. 
Citation: Barkholt P, Vegge A, Clausen TR, Birck MM, Fels JJ, et al. Post-Surgical Effects of Roux-En-Y Gastric Bypass on Glucose Homeostasis, Intestinal Morphology and L-Cells in Obese Göttingen Minipigs. J Obes Bariatrics. 2015;1(1): 8.

Table 4: Volume and mucosal surface of small intestine.

\begin{tabular}{|c|c|c|c|}
\hline & $\begin{array}{c}\text { Control } \\
\text { (control A, B } \\
\text { and C) }\end{array}$ & $\begin{array}{c}\text { Non-responder } \\
\text { (RYGB 3, } 4 \\
\text { and 5) }\end{array}$ & $\begin{array}{c}\text { Responder } \\
\text { (RYGB } 1 \text { and 2) }\end{array}$ \\
\hline \multicolumn{4}{|l|}{ Volume } \\
\hline Small intestine & $64.11 \pm 4.02 \mathrm{~cm}^{3}$ & $\begin{array}{c}103.20 \pm 3.39 \\
\mathrm{~cm}^{3}\end{array}$ & $119.86 \pm 11.15 \mathrm{~cm}^{3}$ \\
\hline $\begin{array}{l}\text { Biliopancreatic } \\
\operatorname{limb}\end{array}$ & $11.80 \pm 0.29 \mathrm{~cm}^{3}$ & $9.16 \pm 0.52 \mathrm{~cm}^{3}$ & $18.00 \pm 2.98 \mathrm{~cm}^{3}$ \\
\hline Alimentary limb & $12.40 \pm 0.76 \mathrm{~cm}^{3}$ & $18.85 \pm 1.28 \mathrm{~cm}^{3}$ & $33.42 \pm 4.72 \mathrm{~cm}^{3}$ \\
\hline Common limb & $39.83 \pm 3.87 \mathrm{~cm}^{3}$ & $\begin{array}{c}75.23 \pm 4.13 \\
\mathrm{~cm}^{3}\left(^{\star}\right)\end{array}$ & $70.45 \pm 18.85 \mathrm{~cm}^{3}$ \\
\hline \multicolumn{4}{|l|}{ Surface } \\
\hline Small intestine & $3620 \pm 493 \mathrm{~cm}^{2}$ & $4918 \pm 648 \mathrm{~cm}^{2}$ & $5994 \pm 54 \mathrm{~cm}^{2}$ \\
\hline $\begin{array}{c}\text { Biliopancreatic } \\
\operatorname{limb}\end{array}$ & $646 \pm 101 \mathrm{~cm}^{2}$ & $355 \pm 23 \mathrm{~cm}^{2}$ & $737 \pm 335 \mathrm{~cm}^{2}$ \\
\hline Alimentary limb & $647 \pm 49 \mathrm{~cm}^{2}$ & $931 \pm 156 \mathrm{~cm}^{2}$ & $1763 \pm 404 \mathrm{~cm}^{2}\left(^{*}\right)$ \\
\hline Common limb & $2327 \pm 347 \mathrm{~cm}^{2}$ & $3633 \pm 589 \mathrm{~cm}^{2}$ & $3493 \pm 685 \mathrm{~cm}^{2}$ \\
\hline
\end{tabular}

Volume of the intestinal wall as well as inner mucosal surface in control $(n=3)$, non-responder $(n=3)$ and responder $(n=2)$ animals. All values are presented as mean \pm SEM.

Table 5: Number of L-cells in small intestine.

\begin{tabular}{|c|c|c|c|}
\hline & $\begin{array}{c}\text { Control } \\
\text { (control A, B and C) }\end{array}$ & $\begin{array}{c}\text { Non-responder } \\
\text { (RYGB 3, 4 } \\
\text { and 5) }\end{array}$ & $\begin{array}{c}\text { Responder } \\
\text { (RYGB 1 and 2) }\end{array}$ \\
\hline Small intestine & $263 \pm 27$ mill & $335 \pm 43$ mill & $482 \pm 14$ mill \\
\hline $\begin{array}{c}\text { Biliopancreatic } \\
\text { limb }\end{array}$ & $13.4 \pm 0.89$ mill & $11.2 \pm 0.94$ mill & $25.0 \pm 16$ mill \\
\hline Alimentary limb & $35.8 \pm 3.5$ mill & $42.5 \pm 2.8$ mill & $110 \pm 36$ mill \\
\hline Common limb & $213 \pm 28$ mill & $281 \pm 45$ mill & $347 \pm 61.1$ mill \\
\hline
\end{tabular}

Absolute number of L-cells in the small intestine and the intestinal limbs in control $(n=3)$, non-responder $(n=3)$ and responder $(n=2)$ animals. All values are presented as mean \pm SEM

A similar effect of RYGB on intestinal hypertrophy has still not been demonstrated in humans and the underlying intestinotrophic mechanism remains elusive. It has been speculated that enhanced mechanical or nutrient stimulation in distal segments of the intestine may be involved in the hypertrophy $[9,44,45]$. This hypothesis is emphasized by the lack of volume change in the biliopancreatic limb where food is not present and previous findings in rats [10,44]. When mechanical and/or nutrient stimulation is missing (e.g. during starvation) the gut undergoes atrophy [46]. An alternative component of gut hypertrophy may be GLP-2, a key mediator of nutrient-stimulated epithelial proliferation, [47] which is co-secreted with GLP-1 from the L-cell in a 1:1 stoichiometric ratio [48]. GLP-2 has been demonstrated to be a very potent stimulator of intestinal proliferation in both adult rats [47] and newborn pigs [17,49] and the stimulation of L-cell number and subsequent increase in total GLP2 secretion could provide a positive feedback mechanism. In this respect, it should be noted that elevated GLP-2 plasma measurements previously have been documented in RYGB animal models and in $\operatorname{man}[7,37]$.

Despite the high number of L-cells in the common limb, the largest alteration between responder and non-responder animals was found to be restricted to the alimentary limb. An approximately 2.5 fold increase in L-cell number in the responder animals compared with non-responders substantiates that this region may be central to the gut endocrine response to RYGB. Interestingly, we observed a strong correlation between the increased number of L-cells and the increased postprandial levels of circulating GLP-1. Elevated postsurgical levels of GLP-1 have also been reported in both pre-clinical and clinical studies of RYGB surgery [6-8] and are considered to play a prominent role in the rapid normalization of glycemia following RYGB [50]. In the present study, pigs were neither hyperglycemic nor glucose intolerant [25], making it impossible to assess potential effects on glycemic control. Our findings regarding both elevated postprandial GLP-1 levels and unchanged glycemia is in agreement with findings in lean RYGB operated Göttingen minipigs [28]. In contrast, the recent paper by Lindqvist and co-workers indicated improvements in glycemic control and pancreas function following RYGB surgery in castrated young male pigs compared with sham operated animals [27]. However, the sham operated controls had fasting blood glucose over $10 \mathrm{mM}$ which is surprising, as to the best of our knowledge no other studies have been able to demonstrate diabetic glucose levels in pigs.

Previous studies indicate that the Göttingen minipig may be superior relative to rodents in studies of severe obesity [22,25]. However, so far most gastric bypass studies in pigs have focused on surgical development or short term survival and include lean animals only[26,29]. Specific anatomic features in minipigs, such as the very thick stomach wall, dense peritoneum and thin small bowel necessitate modifications to the standard RYGB procedure in man [26]. In the five animals that completed the protocol we observed a marked inter-individual weight response to the surgery with two animals losing weight and three animals regaining weight. Weight regain after RYGB has also been reported in humans with complete weight regain in up to $10 \%$ of super obese patients [51,52]. In our study, a weight loss success rate of two out of five successfully operated minipigs was however unexpected. Thus, even though we demonstrate that RYGB surgery of obese Göttingen minipigs is feasible, further surgical optimizations are needed to validate this species as an important translational RYGB model.

A main limitation in our study was the lack of sham-operated control animals. However, we consider it unlikely that the observed adaptations occurred as a response to anesthesia and the extensive manipulation of the visceral organs only, which is supported by data from rats demonstrating no effect of sham surgery on intestinal volume or L-cell numbers when compared to naive controls $[9,10]$.

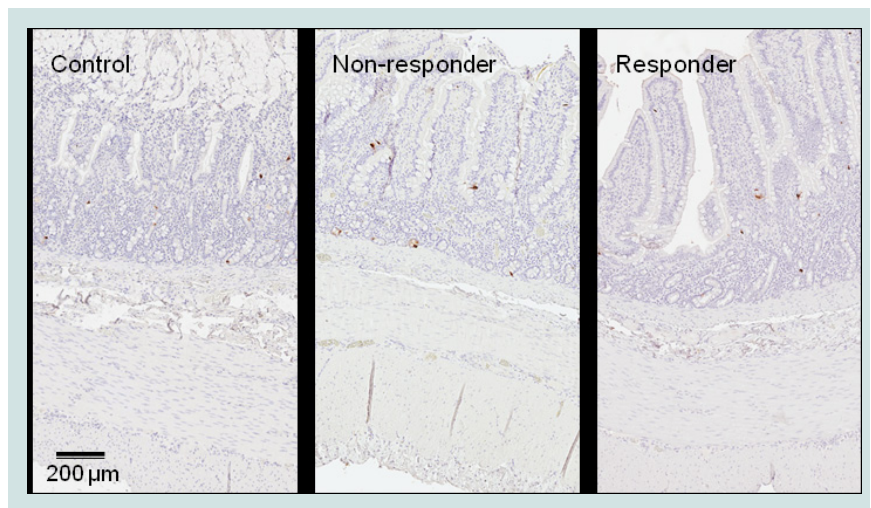

Figure 4: GLP-1 immunohistochemical staining. Representative micrographs of GLP-1 immuno staining in the alimentary limb of control nonoperated minipigs, non-responder and responder RYGB operated minipigs. 
Citation: Barkholt P, Vegge A, Clausen TR, Birck MM, Fels JJ, et al. Post-Surgical Effects of Roux-En-Y Gastric Bypass on Glucose Homeostasis, Intestinal Morphology and L-Cells in Obese Göttingen Minipigs. J Obes Bariatrics. 2015;1(1): 8.

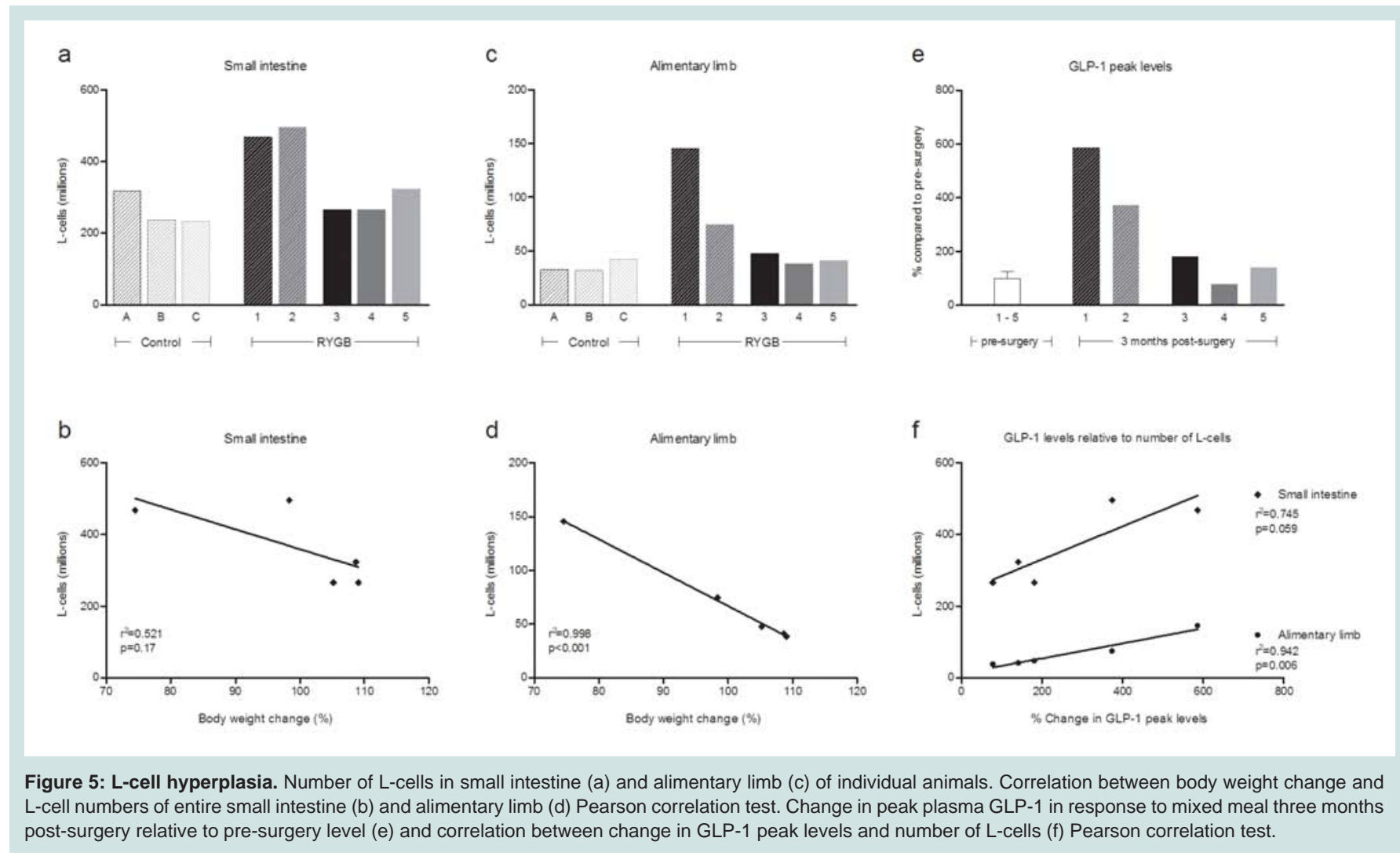

In conclusion, we report that RYGB in obese Göttingen minipigs is associated with hypertrophy of the gut, an increase in absolute L-cell numbers, elevated postprandial GLP-1 levels and decreased leptin levels. Our data suggest that the alimentary limb may be a potential key mediator of the post-surgical effects of RYGB with a significant correlation between morphological changes in this limb and body weight loss.

\section{References}

1. WHO (2014) Obesity and overweight. World Health Organization Fact sheet №311.

2. Mingrone G, Panunzi S, De Gaetano A, Guidone C, laconelli A, et al. (2012) Bariatric surgery versus conventional medical therapy for type 2 diabetes. $N$ Engl J Med 366: 1577-1585.

3. O'Brien PE (2010) Bariatric surgery: mechanisms, indications and outcomes. J Gastroenterol Hepatol 25: 1358-1365.

4. Rubino F, Gagner M, Gentileschi P, Kini S, Fukuyama S, et al. (2004) The early effect of the Roux-en-Y gastric bypass on hormones involved in body weight regulation and glucose metabolism. Ann Surg 240: 236-242.

5. Madsbad S, Dirksen C, Holst JJ (2014) Mechanisms of changes in glucose metabolism and bodyweight after bariatric surgery. Lancet Diabetes Endocrinol 2: 152-164.

6. le Roux CW, Welbourn R, Werling M, Osborne A, Kokkinos A, et al. (2007) Gut hormones as mediators of appetite and weight loss after Roux-en-Y gastric bypass. Ann Surg 246: 780-785.

7. Jacobsen SH, Olesen SC, Dirksen C, Jorgensen NB, Bojsen-Moller KN, et al. (2012) Changes in gastrointestinal hormone responses, insulin sensitivity, and beta-cell function within 2 weeks after gastric bypass in non-diabetic subjects. Obes Surg 22: 1084-1096.

8. Jorgensen NB, Jacobsen SH, Dirksen C, Bojsen-Moller KN, Naver L, et al.
(2012) Acute and long-term effects of Roux-en-Y gastric bypass on glucose metabolism in subjects with Type 2 diabetes and normal glucose tolerance. Am J Physiol Endocrinol Metab 303: E122-131.

9. Mumphrey MB, Patterson LM, Zheng H, Berthoud HR (2013) Roux-en-Y gastric bypass surgery increases number but not density of CCK-, GLP1-, 5-HT-, and neurotensin-expressing enteroendocrine cells in rats. Neurogastroenterol Motil 25: e70-79.

10. Hansen CF, Bueter M, Theis N, Lutz T, Paulsen S, et al. (2013) Hypertrophy Dependent Doubling of L-Cells in Roux-en-Y Gastric Bypass Operated Rats. PLoS One 8: e65696.

11. Bollen P, Ellegaard $L$ (1997) The Gottingen minipig in pharmacology and toxicology. Pharmacol Toxicol 80: 3-4.

12. Miller ER, Ullrey DE (1987) The pig as a model for human nutrition. Annu Rev Nutr 7: 361-382.

13. Patterson JK, Lei XG, Miller DD (2008) The pig as an experimental model for elucidating the mechanisms governing dietary influence on mineral absorption. Exp Biol Med (Maywood) 233: 651-664.

14. Salfen BE, Carroll JA, Keisler DH (2003) Endocrine responses to short-term feed deprivation in weanling pigs. J Endocrinol 178: 541-551.

15. Sheikh SP, Holst JJ, Orskov C, Ekman R, Schwartz TW (1989) Release of PYY from pig intestinal mucosa; luminal and neural regulation. Regul Pept 26: 253-266.

16. Puiman P, Stoll B (2008) Animal models to study neonatal nutrition in humans. Curr Opin Clin Nutr Metab Care 11: 601-606.

17. Vegge A, Thymann T, Lund P, Stoll B, Bering SB, et al. (2013) Glucagon-Like Peptide-2 Induces Rapid Digestive Adaptation Following Intestinal Resection in Preterm Neonates. Am J Physiol Gastrointest Liver Physiol 305: G277-85.

18. Digalakis M, Papamichail M, Glava C, Grammatoglou X, Sergentanis TN et al. (2011) Interposition of a reversed jejunal segment enhances intestinal adaptation in short bowel syndrome: an experimental study on pigs. J Surg Res 171: 551-557. 
Citation: Barkholt P, Vegge A, Clausen TR, Birck MM, Fels JJ, et al. Post-Surgical Effects of Roux-En-Y Gastric Bypass on Glucose Homeostasis, Intestinal Morphology and L-Cells in Obese Göttingen Minipigs. J Obes Bariatrics. 2015;1(1): 8.

19. Kohn F, Sharifi AR, Simianer H (2007) Modeling the growth of the Goettingen minipig. J Anim Sci 85: 84-92.

20. Simianer H, Kohn F (2010) Genetic management of the Gottingen Minipig population. J Pharmacol Toxicol Methods 62: 221-226.

21. Bollen PJ, Madsen LW, Meyer O, Ritskes-Hoitinga J (2005) Growth differences of male and female Gottingen minipigs during ad libitum feeding: a pilot study. Lab Anim 39: 80-93.

22. Raun K, von Voss P, Knudsen LB (2007) Liraglutide, a once-daily human glucagon-like peptide-1 analog, minimizes food intake in severely obese minipigs. Obesity (Silver Spring) 15: 1710-1716.

23. Danielsen KK, Svendsen M, Maehlum S, Sundgot-Borgen J (2013) Changes in body composition, cardiovascular disease risk factors, and eating behavior after an intensive lifestyle intervention with high volume of physical activity in severely obese subjects: a prospective clinical controlled trial. J Obes 2013 325464.

24. Christoffersen B, Golozoubova V, Pacini G, Svendsen O, Raun K (2013) The young Gottingen minipig as a model of childhood and adolescent obesity: influence of diet and gender. Obesity (Silver Spring) 21: 149-158.

25. Johansen T, Hansen HS, Richelsen B, Malmlof R (2001) The obese Gottingen minipig as a model of the metabolic syndrome: dietary effects on obesity, insulin sensitivity, and growth hormone profile. Comp Med 51: 150-155.

26. Flum DR, Devlin A, Wright AS, Figueredo E, Alyea E, et al. (2007) Development of a porcine Roux-en-Y gastric bypass survival model for the study of post-surgical physiology. Obes Surg 17: 1332-1339.

27. Lindqvist A, Spegel P, Ekelund M, Vaz EG, Pierzynowski S, et al. (2014) Gastric bypass improves $\beta$-cell function and increases $\beta$-cell mass in a porcine model. Diabetes 63: 1665-1671.

28. Verhaeghe R, Zerrweck C, Hubert T, Trechot B, Gmyr V, et al. (2014) Gastric Bypass Increases Postprandial Insulin and GLP-1 in Nonobese Minipigs. Eur Surg Res 52: 41-49.

29. Scott DJ, Provost DA, Tesfay ST, Jones DB (2001) Laparoscopic Roux-en-Y gastric bypass using the porcine model. Obes Surg 11: 46-53.

30. Birck MM, Vegge A, Stockel M, Gogenur I, Thymann T, et al. (2013) Laparoscopic Roux-en-Y gastric bypass in super obese Gottingen minipigs Am J Transl Res 5: 643-653.

31. Strader AD, Clausen TR, Goodin SZ, Wendt D (2009) Ileal interposition improves glucose tolerance in low dose streptozotocin-treated diabetic and euglycemic rats. Obes Surg 19: 96-104.

32. Pridal L, Ingwersen SH, Larsen FS, Holst JJ, Adelhorst K, et al. (1995) Comparison of sandwich enzyme-linked immunoadsorbent assay and radioimmunoassay for determination of exogenous glucagon-like peptide-1(7-36)amide in plasma. J Pharm Biomed Anal 13: 841-850.

33. Wilken M, Larsen FS, Buckley D, JJ H (1999) New highly specific immunoassay for glucagon-like peptide 1 (GLP-1). Diabetologia A196.

34. Gundersen HJ, Bagger P, Bendtsen TF, Evans SM, Korbo L, et al. (1988) The new stereological tools: disector, fractionator, nucleator and point sampled intercepts and their use in pathological research and diagnosis. APMIS 96 857-881.

35. Hansen CF, Vrang N, Sangild PT, Jelsing J (2013) Novel insight into the distribution of L-cells in the rat intestinal tract. Am J Transl Res 5: 347-358.

36. Boyce RW, Dorph-Petersen KA, Lyck L, Gundersen HJ (2010) Design-based stereology: introduction to basic concepts and practical approaches for estimation of cell number. Toxicol Pathol 38: 1011-1025.

37. Lutz TA, Bueter M (2014) Physiological mechanisms behind Roux-en-Y gastric bypass surgery. Dig Surg 31: 13-24.

38. Solhaug JH, Tvete S (1978) Adaptative changes in the small intestine following bypass operation for obesity. A radioglocal and histological study. Scand J Gastroenterol 13: 401-408.

39. Dudrick SJ, Daly JM, Castro G, Akhtar M (1977) Gastrointestinal adaptation following small bowel bypass for obesity. Ann Surg 185: 642-648.
40. Brolin RE, Kenler HA, Gorman JH, Cody RP (1992) Long-limb gastric bypass in the superobese. A prospective randomized study. Ann Surg 215: 387-395

41. MacLean LD, Rhode BM, Nohr CW (2001) Long- or short-limb gastric bypass? J Gastrointest Surg 5: 525-530.

42. Choban PS, Flancbaum L (2002) The effect of Roux limb lengths on outcome after Roux-en- $Y$ gastric bypass: a prospective, randomized clinical trial. Obes Surg 12: 540-545.

43. Stylopoulos N, Hoppin AG, Kaplan LM (2009) Roux-en-Y gastric bypass enhances energy expenditure and extends lifespan in diet-induced obese rats. Obesity (Silver Spring) 17: 1839-1847.

44. Taqi E, Wallace LE, de Heuvel E, Chelikani PK, Zheng H, et al. (2010) The influence of nutrients, biliary-pancreatic secretions, and systemic trophic hormones on intestinal adaptation in a Roux-en-Y bypass model. J Pediatr Surg 45: 987-995.

45. Strader AD, Woods SC (2005) Gastrointestinal hormones and food intake Gastroenterology 128: 175-191.

46. Shaw D, Gohil K, Basson MD (2012) Intestinal mucosal atrophy and adaptation. World J Gastroenterol 18: 6357-6375

47. Drucker DJ, Erlich P, Asa SL, Brubaker PL (1996) Induction of intestinal epithelial proliferation by glucagon-like peptide 2. Proc Natl Acad Sci U S A 93: 7911-7916

48. Orskov C, Holst JJ, Knuhtsen S, Baldissera FG, Poulsen SS, et al. (1986) Glucagon-like peptides GLP-1 and GLP-2, predicted products of the glucagon gene, are secreted separately from pig small intestine but not pancreas. Endocrinology 119: 1467-1475.

49. Sangild PT, Tappenden KA, Malo C, Petersen YM, Elnif J, et al. (2006) Glucagon-like peptide 2 stimulates intestinal nutrient absorption in parenterally fed newborn pigs. J Pediatr Gastroenterol Nutr 43: 160-167.

50. Allen RE, Hughes TD, Ng JL, Ortiz RD, Ghantous MA, et al. (2013) Mechanisms behind the immediate effects of Roux-en- $Y$ gastric bypass surgery on type 2 diabetes. Theor Biol Med Model 10: 45

51. Magro DO, Geloneze B, Delfini R, Pareja BC, Callejas F, et al. (2008) Longterm weight regain after gastric bypass: a 5 -year prospective study. Obes Surg 18: 648-651.

52. Himpens J, Verbrugghe A, Cadiere GB, Everaerts W, Greve JW (2012) Longterm results of laparoscopic Roux-en-Y Gastric bypass: evaluation after 9 years. Obes Surg 22: 1586-1593.

\section{Acknowledgements}

The authors would like to thank Susanne Halkier, Christian Rosenquist, Susanne Gøttsche Jacobsen, Pia Von Voss, Gitte Kølander Hansen and Sarah Kampfeldt for skillful technical assistance.

This work was carried out as a part of the research program of the UNIK: Food, Fitness \& Pharma for Health and Disease (www. foodfitnesspharma.ku.dk). The UNIK project is supported by the Danish Ministry of Science, Technology and Innovation. The obese Göttingen minipigs were kindly donated by Novo Nordisk A/S.

The authors would like to state that although parts of the study were carried out at Gubra ApS and Novo Nordisk this does not alter their adherence to all the journal's policies on sharing data and materials. 